\title{
The anticoagulant mechanism of action of recombinant hirudin (CGP 39393) in plasma
}

Citation for published version (APA):

Lindhout, T., Blezer, R., \& Hemker, H. C. (1990). The anticoagulant mechanism of action of recombinant hirudin (CGP 39393) in plasma. Thrombosis and Haemostasis, 64(3), 464-468. https://doi.org/10.1055/s0038-1647337

Document status and date:

Published: 01/01/1990

DOI:

10.1055/s-0038-1647337

Document Version:

Publisher's PDF, also known as Version of record

\section{Please check the document version of this publication:}

- A submitted manuscript is the version of the article upon submission and before peer-review. There can be important differences between the submitted version and the official published version of record.

People interested in the research are advised to contact the author for the final version of the publication, or visit the DOI to the publisher's website.

- The final author version and the galley proof are versions of the publication after peer review.

- The final published version features the final layout of the paper including the volume, issue and page numbers.

Link to publication

\footnotetext{
General rights rights.

- You may freely distribute the URL identifying the publication in the public portal. please follow below link for the End User Agreement:

www.umlib.nl/taverne-license

Take down policy

If you believe that this document breaches copyright please contact us at:

repository@maastrichtuniversity.nl

providing details and we will investigate your claim.
}

Copyright and moral rights for the publications made accessible in the public portal are retained by the authors and/or other copyright owners and it is a condition of accessing publications that users recognise and abide by the legal requirements associated with these

- Users may download and print one copy of any publication from the public portal for the purpose of private study or research.

- You may not further distribute the material or use it for any profit-making activity or commercial gain

If the publication is distributed under the terms of Article $25 \mathrm{fa}$ of the Dutch Copyright Act, indicated by the "Taverne" license above, 


\title{
The Anticoagulant Mechanism of Action of Recombinant Hirudin (CGP 39393) in Plasma
}

\author{
Theo Lindhout, Ron Blezer, and H. Coenraad Hemker \\ From the Department of Biochemistry, University of Limburg, Maastricht, \\ The Netherlands
}

\begin{abstract}
Summary
We studied the inhibitory action of recombinant desulphatohirudin (CGP 39393) on thrombin generation in whole plasma. Human plasma was activated either with thromboplastin or factor IXa. Hirudin delayed thrombin generation, but it was unable to prevent the explosive appearance of thrombin. The dose-dependent prolongation of the lag phase of the intrinsic and extrinsic thrombin generation curve was not the result of titration of thrombin activity by hirudin but the result of a delayed formation of the prothrombin converting complex (prothrombinase). In case of extrinsic activation, hirudin did not affect factor Xa generation, but prolonged the lag phase of the factor Va generation curve, causing its appearance when factor Xa generation was already in the decay phase. Because of its inhibitory action on the thrombin-mediated activation of factor VIII, hirudin prolonged the lag phase of the factor X converting complex that consists of factor IXa and factor VIIIIa. Our observations with hirudin are in keeping with the notion that inhibition of the thrombin-mediated amplification reactions in blood coagulation is a very efficient way to delay or inhibit completely thrombin generation. However, although hirudin neutralizes stoichiometric amounts of thrombin, the interaction between in situ generated thrombin and hirudin appears not to be fast enough to prevent trace amounts of thrombin to activate factors VIII and V. Consequently, an explosive thrombin generation is observed even when free hirudin is present.
\end{abstract}

\section{Introduction}

Hirudin is a very selective tight binding inhibitor of thrombin (1). The dissociation constant of the complex between thrombin and hirudin, isolated from the salivary gland of the leech Hirudo medicinalis, has been reported to be $20 \mathrm{fM}(2)$. The recombinant desulphatohirudin CGP 39393 has a 10-fold lower affinity for thrombin (3). Thus, thrombin activity will be neutralized by hirudin in stoichiometric amounts at extremely low concentrations of both reactants. This makes hirudin the most potent and specific inhibitor of thrombin known. Whether this property can make hirudin a highly potent in vitro anticoagulant in the subject of our present study.

Blood coagulation has to be considered as a process that is controlled by complex feedback systems (4). An essential characteristic of such a system is that small changes in stimulus level can cause very large changes in the response. It is becoming increasingly apparent that the final product of the blood coagulation process, thrombin, is such a feedback stimulus. Activated factor IX and activated factor $\mathrm{X}$ are enzymes with low $\mathrm{k}_{\mathrm{cat}}$ and high $\mathrm{K}_{\mathrm{m}}$ values in their reactions with factor $\mathrm{X}$ and prothrombin, respectively. In the presence of their respective cofactors (factor

Correspondence to: Dr. Th. Lindhout, Dept. of Biochemistry, University of Limburg, P. O. Box 616, 6200 MD Maastricht, The Netherlands
VIIIa or factor Va) and a procoagulant surface (activated blood platelets), factor IXa and factor Xa become very efficient enzymes and it is only then, that factor $\mathrm{Xa}$ and thrombin are produced at high rates $(5,6)$. Interestingly, thrombin has been demonstrated to be the only activator of both factor $\mathrm{V}$ and factor VIII in thromboplastin-activated plasma (7). Moreover, small amounts of thrombin, generated under the influence of trace amounts of tissue factor, were shown to induce procoagulant activity in blood platelets (8). Thus, in view of the tight-binding nature of the interaction between thrombin and hirudin, one might expect that low concentrations of hirudin will prevent the generation of cofactors and thus the explosive generation of thrombin. However, two points remain to be clarified. Firstly, it cannot be excluded that when a potent thrombin inhibitor is present, activated factor $\mathrm{X}$ starts to play a role in the generation of factor VIIIa (9). Secondly, the binding of hirudin to thrombin involves at least two steps: ionic interaction at a site distinct from the active site of thrombin followed by a rearrangement of the complex to form a tighter complex in which hirudin is also (noncovalently) bound to the active site (10). Therefore, besides the extremely high affinity of thrombin for hirudin, the rate of interaction and the effects of other substrates for thrombin on that rate have also to be taken into account, because they might determine to a large extent the anticoagulant potency of hirudin.

In this paper we wish to report on hirudin and its dosedependent effect on thrombin generation in thromboplastin- and factor IXa-activated whole plasma. By monitoring the generation of activated clotting factors at stages before thrombin, we were able to identify the rate limiting steps that determine the overall rate of thrombin generation in the presence of hirudin. It is demonstrated that hirudin at a concentration equivalent to the amount of thrombin formed before the plasma clots, is not sufficient to achieve an anticoagulant effect.

\section{Materials and Methods}

The synthetic peptide substrate Bz-Ile-Glu-(piperidyl)-Gly-Arg-pnitroanilide hydrochloride (S-2337) and H-D-Phe-Pip-Arg-p-nitroanalide hydrochloride (S-2238) were purchased from AB Kabi Vitrum, Sweden. Fatty acid-free human serum albumin was a product of Sigma Chemical Co., St. Louis. Recombinant desulphato-hirudin variant 1 (CGP 39393) was kindly provided by Dr. Wallis, Ciba-Geigy, Horsham, UK. Human brain thromboplastin was prepared by the method of Owren and Aas (11). Its concentration was adjusted with Tris-saline to give a prothrombin time (PT) of $13 \mathrm{~s}$. All reagents used were of the highest grade commercially available.

Purification of proteins. Bovine coagulation factor IXa and human coagulation factor $X$, prothrombin and thrombin were prepared and quantitated as previously described $(12,13)$. Staphylocoagulase was purified by the method described by Hendrix et al. (14).

Preparation of human normal plasma. Blood from healthy donors was collected on $0.13 \mathrm{M}$ trisodium citrate; nine parts of blood to one part of anticoagulant. The blood was centrifugated twice at room temperature for $15 \mathrm{~min}$ at $3,000 \times \mathrm{g}$. A third centrifugation was done at $4^{\circ} \mathrm{C}$ for $1 \mathrm{~h}$ at $23,000 \times \mathrm{g}$. The obtained platelet free plasma was stored at $-80^{\circ} \mathrm{C}$. 


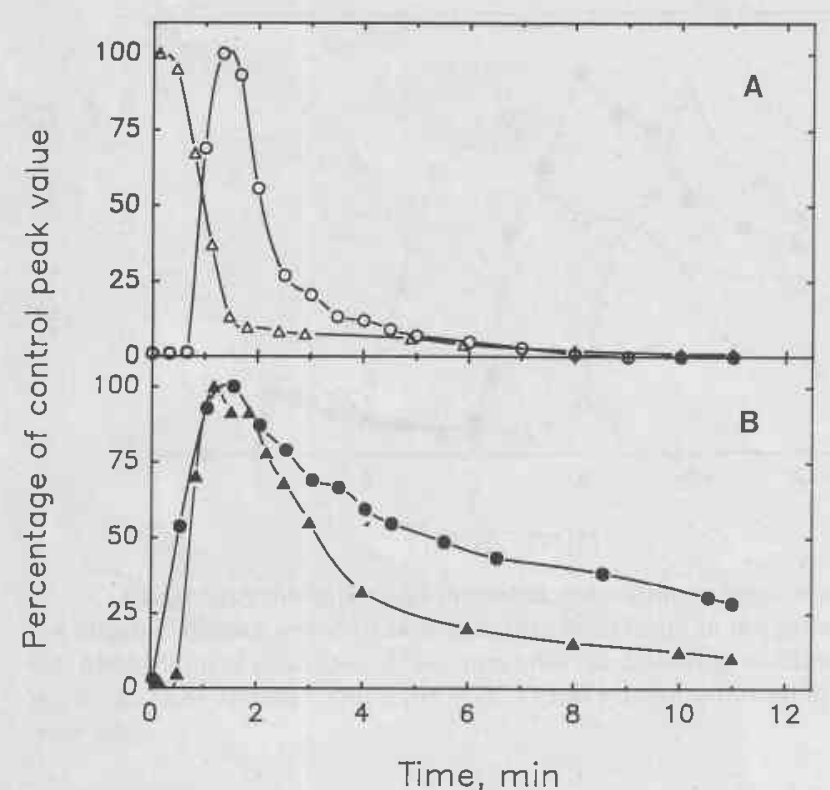

Fig. 1 Generation of activated clotting factors in thromboplastin activated plasma. Panel $A$ : thrombin generation $(O)$ and prothrombin consumption $(\triangle)$; panel B: factor Xa $(\bullet)$ and factor Va $(\Delta)$ generation. The values are expressed as a percentage of the maximum amounts, i.e. $340 \mathrm{nM}$ thrombin, $1.0 \mu \mathrm{M}$ prothrombin, $25 \mathrm{nM}$ factor $\mathrm{Va}, 3 \mathrm{nM}$ factor Xa. The detailed experimental conditions are described under Materials and Methods

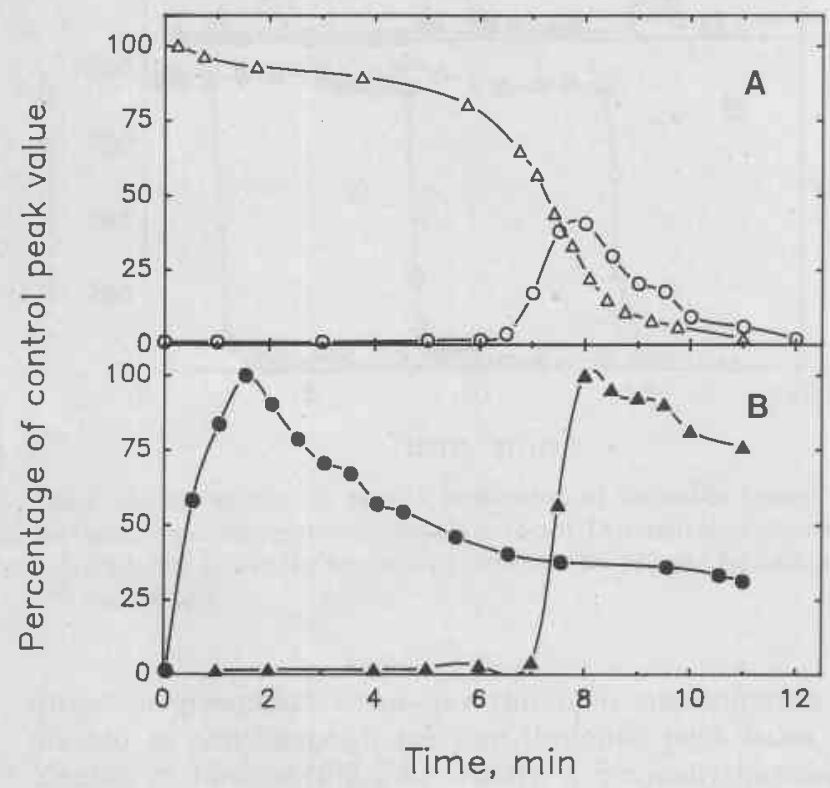

Fig. 2 Effect of hirudin on the generation of activated clotting factors in thromboplastin-activated plasma. The same experimental conditions as in Fig. 1, but in the presence of $450 \mathrm{nM}$ hirudin. Panel A: thrombin generation $(O)$ and prothrombin consumption $(\triangle)$; panel B: factor Xa $(\bullet)$ and factor Va $(\boldsymbol{\Delta})$ generation

Initiation of the extrinsic and intrinsic pathway of plasma clotting. $135 \mu \mathrm{l}$ of citrated human plasma was supplemented with $4 \mu \mathrm{l}$ of Tris-buffer $(50 \mathrm{mM}$ Tris- $\mathrm{HCl}, 175 \mathrm{mM} \mathrm{NaCl}, 0.5 \mathrm{mg}$ human serum albumin $/ \mathrm{ml}$, $\mathrm{pH} 7.9$ ) with or without hirudin, and incubated for $2 \mathrm{~min}$ in a flat-bottom plastic tube while stirring. The plasma was activated by the addition of $6 \mu \mathrm{I} \mathrm{CaCl}_{2}(0.5 \mathrm{M})$ and $5 \mu \mathrm{l}$ of human brain thromboplastin. The clotting time in the absence of hirudin was $45 \mathrm{~s}$.

Intrinsic activation of plasma was performed by incubation of $130 \mu \mathrm{l}$ of plasma with $3.5 \mu \mathrm{l}$ of Tris-buffer with or without hirudin and $3 \mu \mathrm{l}$ phospholipid ( $1 \mathrm{mM} ; 20 \mathrm{~mol} \%$ phosphatidylserine $/ 80 \mathrm{~mol} \%$ phosphatidylcholine), followed by the addition of $7.5 \mu$ l of a factor IXa solution $(1 \mu \mathrm{M})$ and $6 \mu \mathrm{CaCl}_{2}(0.5 \mathrm{M})$. The plasma clotting time in the absence of hirudin was $120 \mathrm{~s}$. All plasma experiments were performed at a free $\mathrm{Ca}^{2+}$ concentration of $4 \mathrm{mM}$, as measured with a calcium-specific electrode standardized with $\mathrm{CaCl}_{2}$ in Tris-buffer.

Monitoring the generation of activated clotting factors. At timed intervals, samples $(5 \mu \mathrm{l})$ were removed from the activated plasma and assayed for factor Va, factor $\mathrm{Xa}$, factor VIIIa and thrombin using specific bioassays and synthetic chromogenic substrates as previously described (7, 15 ). When thrombin was assayed by an amidolytic method, final and sustaining levels of thrombin-like activity were measured as a result of the formation of amidolytic active $\alpha_{2}$-macroglobulin-thrombin complexes. In order to obtain generation curves of free thrombin, we corrected our thrombin measurements according to the method described by Hemker et al. (16).

Briefly, because $\alpha_{2}$-macroglobulin is present in plasma in large excess over free thrombin $(\mathrm{T})$, the formation of thrombin $/ \alpha_{2}$-macroglobulin complex $\left(\alpha_{2}\right.$ M.T) follows pscudo first order reaction kinetics:

$\mathrm{d}\left(\alpha_{2} \mathrm{M} \cdot \mathrm{T}\right) / \mathrm{dt}=\mathrm{k}_{2} \mathrm{~T}$

$\mathrm{k}_{2}$ was determined as in ref. 16 and equals $0.25 \mathrm{~min}^{-1}$, independent of the hirudin concentration. Frec thrombin (T) at any time point $(\mathrm{t})$ is then calculated from the experimentally determined amidolytic activity at that time point $\left(A_{t}\right)$ according to

$T_{t}=A_{t}-f\left(\alpha_{2} M . T\right)_{t}$

where $f$ is the ratio of the amidolytic activity of 1 mole of $\alpha_{2}$ M.T over that of 1 mole of frec thrombin, having a value of 0.56 (16). The correctness of the procedure and of the numerical value of $k_{2}$ was found in the observation of a zero end level of thrombin.

Measurement of prothrombin consumption. Activated plasma samples $(5 \mu \mathrm{l})$ were incubated with $20 \mu \mathrm{l}$ of Tris $(50 \mathrm{mM}), \mathrm{NaCl}(175 \mathrm{mM}), 0.5 \mathrm{mg}$ human serum albumin/ml, $\mathrm{pH} 7.9$ containing $20 \mathrm{mM}$ EDTA and $5 \mu \mathrm{g}$ heparin/ml. An aliquot of $10 \mu 1$ was transferred to a cuvette containing Tris-buffer and S-2238 $(0.2 \mathrm{mM})$ to determine the amount of thrombin complexed with $a_{2}$-macroglobulin. Another $10 \mu \mathrm{l}$-aliquot of the first incubation mixture was incubated with staphylocoagulase $(0.5 \mu \mathrm{M})$ for $2 \mathrm{~min}$. The activity formed as a result of the stoichiometric interaction between prothrombin and staphylocoagulase was measured using S-2238 as described. The amount of prothrombin in the activated plasma samplc was then calculated from the difference between both determinations. A standard curve was constructed from known amounts of purified human prothrombin.

\section{Results}

\section{Thromboplastin-Activated Plasma}

Incubation of citrated plasma with thromboplastin and free calcium ions $(4 \mathrm{mM})$ under the conditions as described in Materials and Methods, resulted after a short lag phase in a sudden onset of thrombin generation, followed by a decay phase (Fig. 1A). Values are given as percentage of the thrombin peak value.

Obviously, the somewhat delayed thrombin generation is the result of a delayed onset of prothrombin conversion (Fig. 1A). From Fig. $1 \mathrm{~B}$ it becomes evident that the rapid conversion of prothrombin is related to the appearance of factor $\mathrm{Va}$, and not at all to that of factor $\mathrm{Xa}$. This is in keeping with the notion that significant amounts of thrombin can only be generated when the prothrombin converting complex (prothrombinase), that consists of activated factor $\mathrm{X}$ and activated factor $\mathrm{V}$ assembled at a phospholipid surface, is formed. Thus, the delayed $(30 \mathrm{~s})$ appearance of factor $\mathrm{Va}$ is the rate limiting step in the formation of the prothrombinase complex and regulates the onset of thrombin generation.

The same experiment, but than performed in the presence of hirudin $(450 \mathrm{nM})$, clearly showed that hirudin had two effects on 


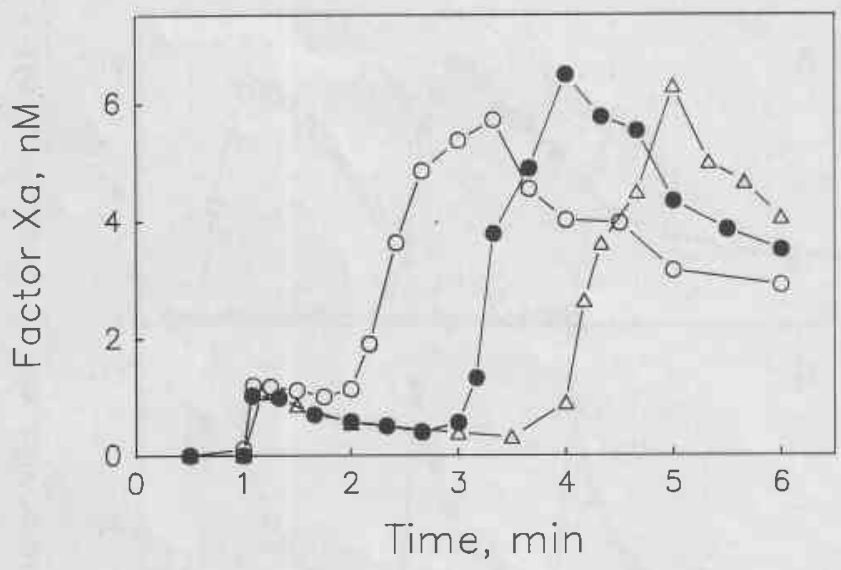

Fig. 3 Exogenous thrombin and thrombin generation in plasma containing hirudin. Plasma was activated with thromboplastin in the presence of $600 \mathrm{nM}$ hirudin as described. Three min later the following additions were made: $150 \mathrm{nM}$ human $\alpha$-thrombin (O), $75 \mathrm{nM}$ human $\alpha$-thrombin $(\bullet)$ or none $(\triangle)$

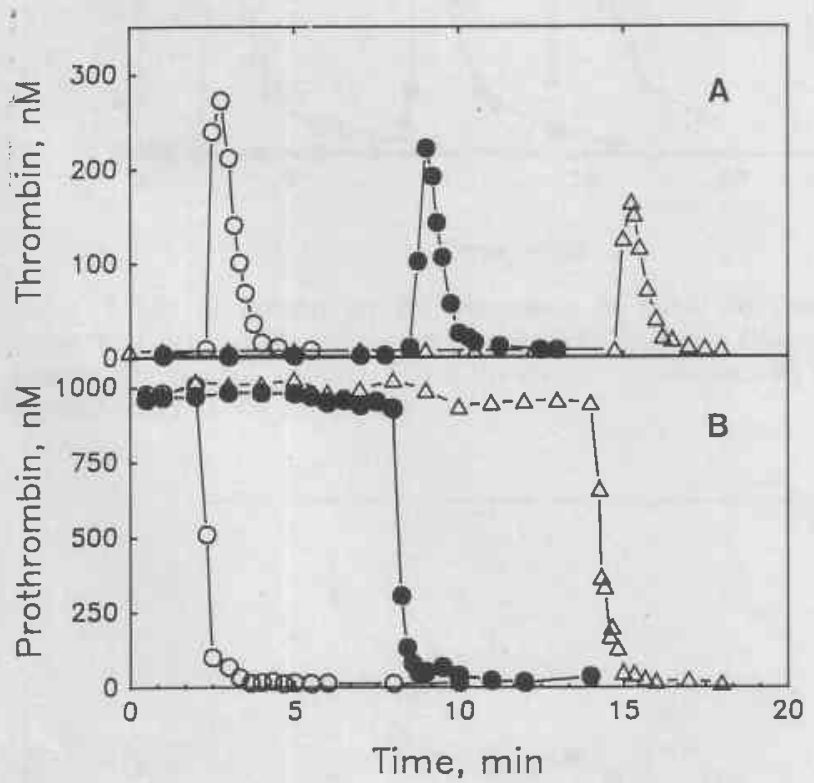

Fig. 4 Effect of hirudin on the generation of thrombin (panel A) and prothrombin consumption (panel B) in factor IXa-activated plasma. Symbols indicate: $(O)$ in the absence of hirudin, $(\bullet) 150 \mathrm{nM}$ hirudin, and $(\triangle)$ $300 \mathrm{nM}$ hirudin

thrombin generation when free thrombin concentration is expressed as percentage of the free thrombin peak value in the absence of hirudin (Fig. 2A). Firstly, a markedly increased lag phase of thrombin generation is seen, which reflects the prolongation of the plasma clotting from $45 \mathrm{~s}$ in the absence of hirudin to $8 \mathrm{~min}$ in the presence of $450 \mathrm{nM}$ hirudin. Secondly, the amount of free thrombin that could be generated is greatly reduced. Both observations could be explained by assuming a simple titration phenomenon in which the first amounts of thrombin formed are neutralized by hirudin. However, the prothrombin consumption curve (Fig. 2 A) shows that at the time of rapid onset of thrombin generation, the rate of prothrombin conversion increased drastically. Apparently, the increased lag phase of the thrombin generation curve is the result of the inhibitory action of hirudin on the reactions that are involved in the generation of the prothrombinase complex.

When we compare the effect of hirudin on factor Xa generation and factor Va generation (Fig. 2B) it is clear that hirudin delayed the appearance of factor Va but not that of factor Xa. Evidently, factor $\mathrm{Xa}$ is not involved in the generation of factor $\mathrm{Va}$, thus inhibition of factor Va generation is solely caused by the hirudin-dependent inhibition of the first traces of thrombin. If so, one expects the onset of thrombin generation after all hirudin is complexed with thrombin. According to the prothrombin consumption measurements (Fig. $2 \mathrm{~A}$ ), onset of thrombin generation was observed when $25 \%$ of the prothrombin was converted and thus $250 \mathrm{nM}$ thrombin generated. These findings suggest that during in situ thrombin generation, traces of thrombin that are not neutralized by hirudin trigger further thrombin generation by activation of factor $\mathrm{V}$.

To test this hypothesis, the following experiments were performed. Plasma was incubated with thromboplastin in the presence of $600 \mathrm{nM}$ hirudin. The onset of thrombin generation was seen at $10 \mathrm{~min}$ (Fig. 3). Addition of purified human $\alpha$-thrombin $(150 \mathrm{nM}), 3 \mathrm{~min}$ after thromboplastin/calcium, caused an instantenous generation of thrombin activity and plasma clot formation. Thus, although hirudin is present in excess over the amount of thrombin added, a true burst of thrombin activity is seen. In fact, most of the thrombin added was immediately neutralized as found by rapid subsampling (every $5 \mathrm{~s}$ ). This is more clearly seen when less thrombin $(75 \mathrm{nM})$ is added. The thrombin activity gradually increased until a burst. These findings suggest that part of the exogenous thrombin survives the inhibitory action of hirudin long enough to activate factor $\mathrm{V}$. At both exogenous thrombin concentrations complete activation of plasma factor $V$ was observed (data not shown).

\section{Factor IXa-Activated Plasma}

Increasing amounts of hirudin added to plasma that was incubated with factor IXa, phospholipid and calcium, caused a dose-dependent prolongation of the lag phase of the freethrombin generation curve. In addition, reduced peak values of free thrombin concentrations were observed (Fig.4A). Fig. 4B shows that prothrombin consumption is negligable before the burst of thrombin activity. These observations are qualitatively not different from those found when plasma was activated with thromboplastin. However, from Fig. 5 it becomes apparent that the lag phase of the factor IXa-induced thrombin generation curve is caused by a different mechanism. In spite of the relative high amount of factor IXa added to the plasma, factor Xa generation did show a lag phase (Fig.5A). Apparently, factor IXa, even at a concentration half the plasma level of factor IX, is unable to generate factor $\mathrm{Xa}$ at a significant rate. From Fig. $5 \mathrm{~B}$ it becomes clear that the rate limiting step in the generation of the factor $\mathrm{X}$ converting complex is the generation of the cofactor (factor VIIIa). Hirudin dramatically increased the lag time of factor $\mathrm{Xa}$ generation. This finding strongly suggests that neutralization of thrombin by hirudin caused the observed delay in factor VIIIa generation. However, it is in that case not easy to conceive how a burst of thrombin activity could occur. From the prothrombin consumption curves (Fig. 4B) it is clearly seen that prior to the time point of the sudden onset of an extremely rapid prothrombin consumption much less thrombin has been generated than the amount of free hirudin initially present. The areas under the thrombin generation curves decreased proportionally with increasing hirudin concentrations, indicating that most of the hirudin is consumed after the sudden onset of thrombin generation (Fig. 4). These observations point at a role of factor Xa in the activation of factor VIII when thrombin activity is blocked by hirudin.

This notion was tested in the following way. The addition of factor Xa to plasma that was incubated for $1 \mathrm{~min}$ with factor IXa, almost immediately caused a burst of factor Xa activity (Fig. 6). 


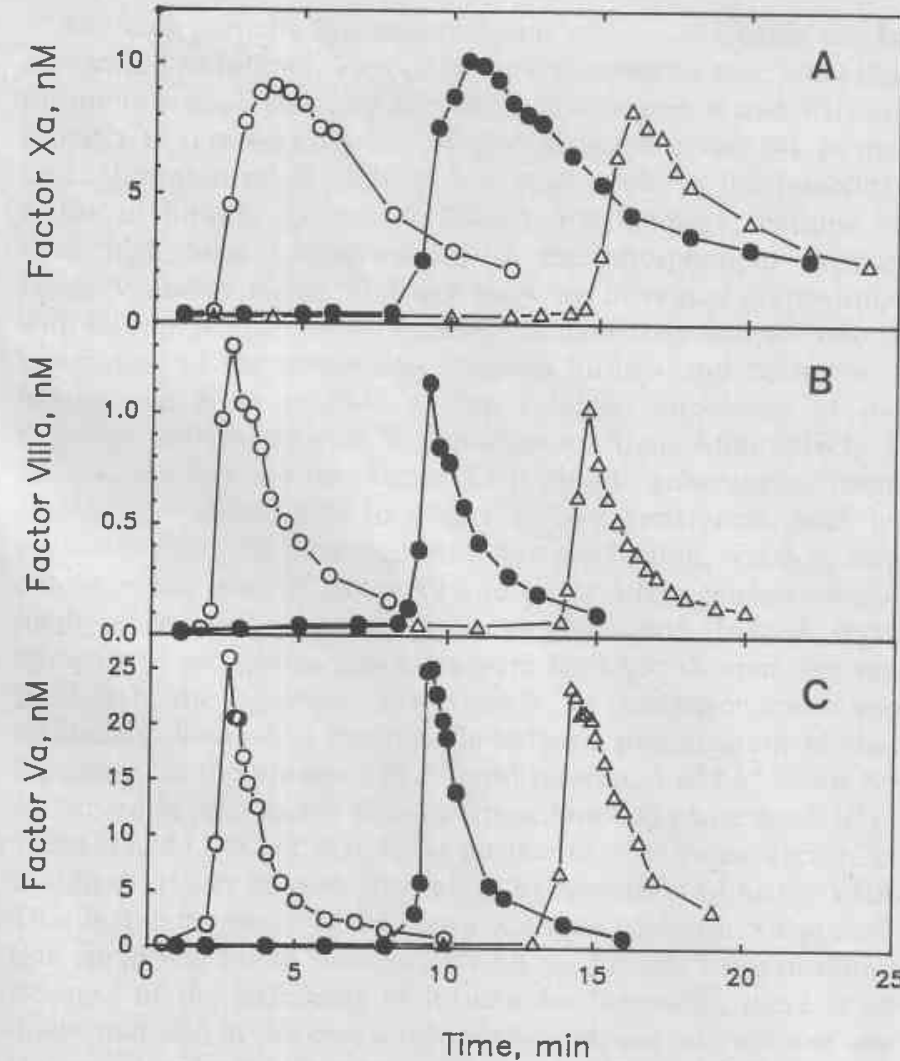

Fig. 5 Effect of hirudin on the generation of factor Xa (panel A), factor VIIIa (panel B) and factor Va (panel C) in factor IXa-activated plasma. The symbols indicate: $(\bigcirc)$ in the absence of hirudin, (O) $150 \mathrm{nM}$ hirudin, and $(\triangle) 300 \mathrm{nM}$ hirudin

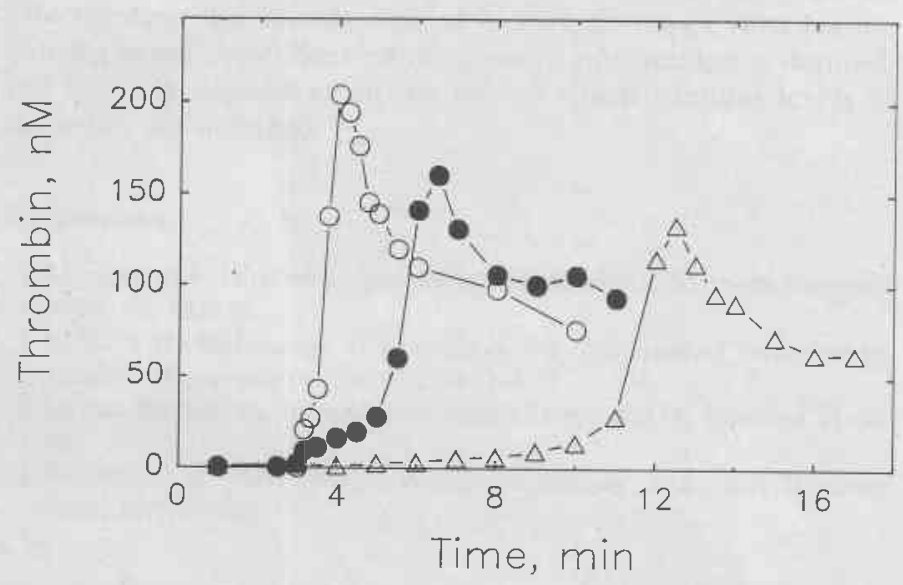

Fig. 6 Exogenous factor $\mathrm{Xa}$ and factor $\mathrm{Xa}$ generation in plasma containing hirudin. Plasma was activated with [factor IXa $(50 \mathrm{nM})$, phospholipid $(20 \mu \mathrm{M})$, free calcium ions $(4 \mathrm{mM})]$ in the absence $(0)$ or presence of $250 \mathrm{nM}(\triangle)$ and $500 \mathrm{nM}(\triangle)$ hirudin. Human factor Xa $(1 \mathrm{nM})$ was added 1 min after factor IXa

When the same experiment was performed in the presence of hirudin, the burst of factor Xa was delayed. However, the lag time was drastically shortened: from $15 \mathrm{~min}$ in the presence of $300 \mathrm{nM}$ hirudin and no factor Xa (Fig. 5B) to 3 min when $1 \mathrm{nM}$ of factor Xa was added. Of interest is to note that the decay of exogenous factor $\mathrm{Xa}$ is not affected by hirudin. Thus, whereas these findings indicate that factor $\mathrm{Xa}$ is able to trigger its own generation, it is not quite clear whether this is the result of a direct activation of factor VIII. In this respect it is important to note that hirudin does prolong the lag phase of the factor Xa generation curve.

\section{Discussion}

Based upon our current knowledge of the remarkable properties of hirudin as a very specific and strong inhibitor of thrombin, one might expect a simple anticoagulant mechanism of action of this drug: neutralization of formed thrombin in stoichiometric amounts. Consequently, it might be believed that the effective dose of hirudin, as an antithrombotic drug, is the amount which titrates the amount of thrombin generated in a given thrombotic situation (17).

However, once coagulation is initiated, thrombin induces an extremely powerful amplification of its own generation. Also, it must be realized that a number of natural subtrates for thrombin will compete with hirudin for the same site on thrombin. If such a competition exists, then the rate of interaction between thrombin and hirudin should decrease; thereby rendering hirudin a slowbinding inhibitor (18).

Our basic finding is that, at least during in vitro plasma clotting, the anticoagulant potency of hirudin is less than one might expect from a fast and tight-binding inhibitor of thrombin. During extrinsic clotting in the presence of hirudin, a slow rate of prothrombin consumption was observed before the onset of rapid thrombin generation (Fig. 2). However, it seems that the amount of prothrombin consumed (thus total thrombin generated) is still less than the total amount of hirudin. The very same was observed during factor IXa-induced thrombin generation. Before the sudden onset of thrombin generation, no significant prothrombin consumption could be detected (Fig. 4). Thus, at the time of appearance of thrombin activity the effective hirudin concentration was not significantly diminished. Yet, an explosive burst of thrombin activity was seen.

These observations are readily explicable by consideration of the factors that determine the lag phase and the rate of prothrombin consumption and thus prothrombinase formation. When clotting is initiated by the addition of factor IXa, the only event that determines the generation of factor $\mathrm{Xa}$ is the activation of factor VIII, because factor IXa activity is not neutralized whether or not hirudin is present (19).

From the extrinsic clotting experiments it is known that generation of factor $\mathrm{Xa}$ alone is not sufficient to obtain a rapid generation of thrombin. The rate limiting step in the generation of the prothrombin converting complex (prothrombinase) is the activation of factor $\mathrm{V}$ by thrombin (Fig. 2 and refs 9, 15, 20). Indeed, small amounts $(1 \mathrm{nM})$ of exogenous factor Va drastically decreased the lag-time period of thrombin in factor IXa-activated plasma (Lindhout, unpublished results) and addition of activated factor VIII abolished the lag phase of thrombin generation, even in the presence of heparin (20). Overall, the linked positive feedback reactions by which the essential cofactors Va and VIIIa, are generated, form the basis of a sudden onset of the generation of the prothrombinase complex after a lag phase that is needed to generate sufficient amounts of factor $\mathrm{Xa}$ and factor $\mathrm{Va}$ to build the prothrombinase complex.

The intriguing observation with hirudin is that this potent thrombin inhibitor is unable to prevent the formation of the prothrombinase complex, knowing that during the lag phase of intrinsic clotting, thrombin is generated at a very slow rate. During the lag phase of extrinsic clotting a higher rate of thrombin generation was found because in this case the generation of factor $\mathrm{Xa}$ is not inhibited. Therefore, it is not quite unexpected that more hirudin is required to achieve an anticoagulant effect in the latter case than in the former one. 
The unexpectedly low anticoagulant activity of hirudin can be considered as follows. First of all, it is reasonable to assume that thrombin is generated at a site where also factors V and VIII are found, i. e. at or very close to the phospholipid surface (4). In that case, thrombin might become less susceptible to the inhibitory action of hirudin (protective effect). Furthermore, because of their high local concentrations at the phospholipid surface, factor $\mathrm{V}$ and/or factor VIII will show an increased competition with hirudin for thrombin. We could demonstrate that the rate of association of the interaction between hirudin and thrombin is indeed too slow relative to the catalytic effeciency of the thrombin-catalyzed factor $\mathrm{V}$ activation reaction. Alternatively, it cannot be ruled out that factor $\mathrm{Xa}$ is able to generate sufficient amounts of factor VIIIa to trigger its own generation. Such an event will cause an increased thrombin production, which in turn enhances the rates of factor Va and factor VIIIa generation and finally ends in an explosive thrombin generation. Indeed, small amounts of exogenous factor Xa were found to shorten, but not to abolish, the lag phase of the factor $\mathrm{Xa}$ generation curve and drastically diminished the hirudin-induced prolongation of that lag phase. In the presence of $250 \mathrm{nM}$ hirudin, $1 \mathrm{nM}$ of factor Xa added $1 \mathrm{~min}$ after factor IXa, shortened the lag phase from 10 to $3 \mathrm{~min}$ (Fig. 6). As yet, it remains unclear to what extent factor Xa is able to trigger its own generation by activation of factor VIII. That is, the lag phase of the factor $\mathrm{Xa}$-induced factor $\mathrm{Xa}$ generation curve was found to increase with the hirudin concentration. Because of the specificity of hirudin for thrombin, there is no doubt that also in this case a thrombin-catalyzed activation of one (factor $\mathrm{V}$ ) or both cofactors is initiating further factor Xa generation. Therefore, the alternative explanation for the observed effect of exogenous factor Xa might be the ultra sensitivity of the intrinsic plasma clotting pathway for extremely small changes in rates of thrombin generation as could be induced by exogenous factor $\mathrm{Xa}$. It is this sensitivity which makes that the anticoagulant effectiveness of a certain dose of hirudin during in vitro plasma clotting is not dependent on the amount of thrombin generated, but is solely dependent on the rate at which stimulus levels of thrombin are obtained.

\section{References}

1 Markwardt F. Hirudin as an inhibitor of thrombin. Methods Enzymol 1970; 69: 924-32.

2 Stone S R, Hofsteenge J. Kinetics of the inhibition of thrombin by hirudin. Biochemistry 1986; 25 : 4622-8.

3 Grossenbacher H. Information sheet CIBA-GEIGY, released 11-0888 .

4 Jackson C M, Nemerson Y. Blood coagulation. Annu Rev Biochem 1980; 49: 765-811.
5 Rosing J, Tans G, Govers-Ricmslag J W P, Zwaal R F A, Hemker H C. The role of phospholipids and factor $\mathrm{Va}$ in the prothrombinase complex. J Biol Chem 1980; 255: 274-83.

6 Van Dicijen G, Tans G, Rosing J, Hemker H C. The role of phospholipid and factor VIIIa in the activation of bovine factor X. J Biol Chem 1981; 256: 3433-42.

7 Pieters J, Lindhout T, Hemker H C. In situ generated thrombin is the only cnzyme that effectively activates factor VIII and factor $\mathrm{V}$ in thromboplastin-activated plasma. Blood 1989; 74: 1021-4.

8 Béguin $\mathrm{S}$, Lindhout $\mathrm{T}$, Hemker $\mathrm{H} \mathrm{C}$. The effect of trace amounts of tissue factor on thrombin generation in platelet rich plasma, its inhibition by heparin. Thromb Haemostas 1989; 61: 25-9.

9 Ofosu F A, Hirsh J, Esmon C T, Modi G J, Smith L M, Anvari N, Buchanan M R, Fenton J W, Blajchman M A. Unfractionated heparin inhibits thrombin-catalyzed amplification reactions of coagulation more efficiently than those catalyzed by factor Xa. Biochem J 1989; 257: 143-50.

10 Braun P J, Dennis S, Hofsteenge J, Stone S R. Use of site-directed mutagenesis to investigate the basis for the specificity of hirudin. Biochemistry 1988; 27: 6517-22.

11 Owren P A, Aas K. The control of dicoumarol therapy and the quantitative determination of prothrombin and proconvertin. Scand $\mathbf{J}$ Clin Lab Invest 1951; 3: 201-18.

12 Pieters J, Willems G, Hemker H C, Lindhout T. Inhibition of factor IXa and factor Xa by antithrombin III/heparin during factor $\mathrm{X}$ activation. J Biol Chem 1988; 263: 15313-8.

13 Schoen P, Lindhout T, Willems G, Hemker H C. Antithrombin IIIdependent anti-prothrombinase activity of heparin and heparin fragments. J Biol Chem 1989; 264: 10002-7.

14 Hendrix H, Lindhout $T$, Mertens $\mathrm{K}$, Engels W, Hemker H C. Activation of human prothrombin by stoichiometric levels of staphylocoagulase. J Biol Chem 1983; 258: 3637-44.

15 Pieters $J$, Lindhout $\mathrm{T}$. The limited importance of factor Xa inhibition to the anticoagulant property of heparin in thromboplastin-activated plasma, Blood 1988; 72: 2048-52.

16 Hemker H C, Willems G, Béguin S. A computer assisted method to obtain the prothrombin activation velocity in whole plasma independent of thrombin decay processes. Thromb Haemostas 1986; 56: 9-17.

17. Talbot M D, Ambler J, Butler K D, Findlay V S, Mitchell K A, Peters R F, Tweed M F, Wallis R B. Recombinant desulphatohirudin (CGP 39393) anticoagulant and antithrombotic properties in vivo. Thromb Haemostas 1989; 61: 77-80.

18 Hofsteenge J, Taguchi H, Stone S R. Effect of thrombomodulin on the kinetics of the interaction of thrombin with substrates and inhibitors. Biochem J 1986; 237: 243-51.

19 Pieters J, Lindhout T, Willems G. The heparin-stimulated inhibition of factor IXa generation and factor IXa neutralization in plasma. Blood 1990; 76: 549-54.

20 Béguin S, Lindhout T, Hemker H C. The mode of action of heparin in plasma. Thromb Haemostas 1989; 60: 457-62.

Received April 3, 1990 Accepted after revision July 2, 1990 